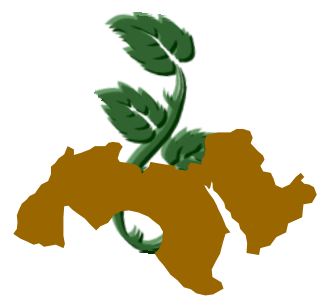

Arab Univ.

\title{
PRODUCTION AND CHARACTERIZATION OF AN EXTRACELLULAR HA- LO-ALKALINE PROTEASE PRODUCED BY Bacillus ISOLATES FROM FESEEKH (Mujil auratus) PRODUCTS
}

\author{
Samah H. Abuhussien ${ }^{1}$; Fatma R. Nassar'; Sohair A. Nasr ${ }^{1}$ and \\ A.A.M. Abdelhafez ${ }^{1}$ \\ 1- Department of Agricultural Microbiology, Faculty of Agriculture, Ain Shams Univ., Shobra \\ El-Kheima Cairo, Egypt
}

Keywords: Alkaline protease, Bacillus sp., Microbial enzymes, Enzyme production, Salted fish

\section{ABSTRACT}

Ninety five isolates were collected from commercially and laboratory manufactured feseekh products and tested for protease production on standard skim milk agar and gelatin media supplemented with $15 \% \mathrm{NaCl}$ salt. They were identified to be Bacillus isolates. Out of the 95 isolates, three Bacillus isolates (11pb, 14pb, 13pb) were selected based on their highest protease production. Five media were tested for select the most suitable medium for production by the three above isolates. Fish by-product medium gave the highest protease production by the three isolates, reaching $126.5,136.5,147.5 \mathrm{u} / \mathrm{ml}$ by $11 \mathrm{pb}, 14 \mathrm{pb}, 13 \mathrm{pb}$, respectively. These levels were obtained between late logarithmic growth phase and beginning of stationary phase for the isolates. The highest Protease production was obtained at $\mathrm{pH} 8$, temperature $30^{\circ} \mathrm{C}$ and $\mathrm{NaCl}$ concentration $5 \%$, the enzyme was stable at temperature ranged between 60 and $65^{\circ} \mathrm{C}$ during the period tested $(1 \mathrm{~h})$ and the protease was optimally active at $\mathrm{pH} 10$ and $60^{\circ} \mathrm{C}$. The enzyme was stable for 10 days at $30{ }^{\circ} \mathrm{C}$ during the period tested (1 month) where it lost $10 \%$ of its activity after 20 days while lost $85 \%$ of its activity after 30 days of storage at $30^{\circ} \mathrm{C}$. These properties make the enzyme suitable for detergent industry.

\section{INTRODUCTION}

Fish and fish products play an important role in the diets of West African countries. In Egypt, "feseekh" is the Arabic name for salted fermented Bouri fish, where whole non-eviscerated fish are washed by tap water, and left to decompose for one day to three days, depending on the weather, before salting. The salting process involves stuffing of the gills and covering the entire fish with approximately $15-25 \%$ salt by weight, followed by aging at room temperature for suitable period of time, depending on salt concentration, and is characterized by its specific flavor and its sharp penetrating odor. This odor permeates the air in and around selling shops and gives the area a characteristic smell (FAO, 1992).

Enzymes especially bacterial proteases and lipases, are expected to be greatly responsible for the feseekh ripening process and flavor development. Amino acids and volatile compounds producing during maturation as example are mostly responsible for producing flavor. Therefore, the quantitative determinations of such chemical compounds during ripening may contribute to flavor quality and grade (Essuman, 1992). Moreover, enzymes have been used for centuries as processing aids in the manufacture of food products to improve their qualities, solubility, and stability (Joo et al 2003).

About $50 \%$ of the enzymes used as industrial processing aids are proteases, which have been used in a number of industrial applications such as laundry detergents, feed and leather treatment (Ming, et al 1992), as well as silk de-gumming, cheese making, chill proofing, meat tenderizing, fermented sauces and the production of pharmaceuticals (Rao, et al 1998). These enzymes have also been used for waste management and silver recovery (Gupta, et al 2002). Therefore many types of proteases (acid, alkaline and neutral) have been studied. Moreover, the production of halophilic enzymes using halophilic bacteria may be 
applied in purification of polymer containing wastes using these halophilic microorganisms. Also, these proteases can improve fish sauce production (Kim and Kim, 2005).

Highly active proteases have been purified from soy sauce halophiles, such as Bacillus subtilis CCKS-118 (Choi et al 1996), B. subtilis CCKS-111 (Choi and Kim, 1997), Halobacterium sp. (An et al 1990) and Aspergillus sp. FC-10 (Su and Lee, 2001), from fish sauce $B$. subtilis FS-2 (Nagao and To, 2000), soil B.subtilis Y-108 (Yang et al 2000) and CF80 (Watanabe, 2003) and poultry waste $B$. subtilis KS-1 (Su and Lee, 2001).

The objective of this study was to isolate and characterize salt tolerant protease from fermented feseekh as a starter for fish sauce with high salt concentration. Hence, strong proteolytic bacteria were isolated from feseekh and sardine samples with $15 \% \mathrm{NaCl}$ salt during maturation and spoilage stages, and its proteases were studied.

\section{MATERIALS AND METHODS}

\section{Materials}

Sixety feseekh samples were collected from local markets of five regions of cairo, and transported in sanitized plastic containers filled with product brine solution and transferred to lab in the same day. For laboratory manufactured feseekh, samples were manufactured due to (Rashad, 1986).

\section{Methods}

\subsection{Production of protease by fish isolated bacteria}

\subsubsection{Screening, Isolation and purification of proteolytic Bacillus isolates}

For isolation of proteolytic isolates, the ninety five isolates were collected from feseekh products using laboratory and commercially manufactured samples, skim milk agar with $10 \% \mathrm{NaCl}$ was used (Shumi, et al 2004). The isolates were purified by sub-culturing on skim milk agar medium. The purified bacterial isolates were transferred onto trypton glucose yeast extract agar (TGYA) slants and then preserved as stock cultures. The primary screening was done by liquefying of gelatin then hydrolysis of skimmed milk casein with $0 \%, 5 \%$ and $10 \% \mathrm{NaCl}$. Plates were incubated at $37^{\circ} \mathrm{C}$ for $24 \mathrm{hrs}$. Clear zones of skim milk hydrolysis were used as an indication of protease production (Shumi, et al
2004). Depending on the zone clearness and $\mathrm{NaCl}$ concentrations, ninety five isolates were selected for further experimental studies.

\subsubsection{Determination of the specific growth rates}

Inoculum was prepared by transferring a loopfull from each isolate from 24 old cultures on nutrient agar slants, into $25 \mathrm{ml}$ of TGY broth medium and incubated on a rotary shaker (100 rpm) at 37 ${ }^{\circ} \mathrm{C}$ for $24 \mathrm{~h}$. During this period, samples were taken for the determination of total count, in order to estimate the specific growth rates. The inoculum concentration for the actual fermentation of each isolate was based on the optical density at the end of the exponential phase. The aim was to standardize the inoculum amount for each experiment based on the growth rate of the first sub-culture.

\subsubsection{Media used for protease production}

Five broth media were used to select the most suitable media for protease production with the three isolates. Media used were (1): Casein broth, (Shumi, et al 2004) (casein, 3\%; $\mathrm{NaNO}_{3}, 0.5 \%$; $\mathrm{K}_{2} \mathrm{HPO}_{4}, 0.55 ; \mathrm{MgSO}_{4} .7 \mathrm{H}_{2} \mathrm{O}, 0.02 \% ; \mathrm{Na}_{2} \mathrm{CO}_{3}, 1 \%$ ), (2): Gelatine broth, (Shumi, et al 2004) (gelatine,3\%; $\mathrm{K}_{2} \mathrm{HPO}_{4}, 0.2 \%$; glucose $0.1 \%$;peptone $0.5 \%)$, (3): Tryptone Glucose Yeast extract broth (TGY), (Shumi, et al 2004), medium (4): 1\% peptone medium, (Shumi, et al 2004) containing $1 \%$ peptone, $2.9 \mathrm{mM} \mathrm{K}_{2} \mathrm{HPO}_{4}$ and $5 \mathrm{mM} \mathrm{MgCl}_{2}$ and medium (5): fish by-product medium was composed only from fish by-products powder (10 g/l), (Ellouz, et al 2001). The selected isolates were grown in $250 \mathrm{~mL}$ Erlenmeyer flasks containing $50 \mathrm{ml}$ of each of the above production media at $\mathrm{pH}$ 7.0. Media were inoculated with $1 \mathrm{ml}$ inoculum $(1.8 \mathrm{x}$ $\left.10^{8}\right)$ and aliquot samples were taken at $2 \mathrm{~h}$ intervals and centrifuged at $15000 \mathrm{rpm}$ for $15 \mathrm{~min}$ at $4^{\circ} \mathrm{C}$ and the supernatants were examined for enzyme activity (Amozeegar, et al 2007).

\subsection{Protease assay}

\subsubsection{Protease assay for halotolerant iso- lates}

The protease activity was determined by casienolytic modified method of Kembhavi, et al 1993. using casein as a substrate, one $\mathrm{ml}$ aliquot of the culture supernatant was mixed with $3 \mathrm{ml}$ of $1 \%$ casein ( $\mathrm{pH} 7$ adjusted with Tris- $\mathrm{HCl}$ buffer) and 
incubated for $15 \mathrm{~min}$ at $60^{\circ} \mathrm{C}$. The reaction was stopped by adding $3 \mathrm{ml}$ of Trichloroacetic acid (7.5 $\%)$. The mixture was allowed to stand at room temperature for $15 \mathrm{~min}$, filtrated using filter paper Whatman no. 1 and the absorption was measured at $280 \mathrm{~nm}$. Blank was prepared in which $3 \mathrm{ml} \mathrm{TCA}$ was added before incubation (Alsheheri and Mostafa, 2004). All samples were measured in triplicate. A standard curve was generated using solutions of $0-50 \mathrm{mg} / \mathrm{l}$ tyrosine. One unit of protease activity was defined as the amount of enzyme required to liberate one microgram tyrosine per milliliter in $1 \mathrm{~min}$ under the experimental conditions used (Shumi, et al 2004).

\subsubsection{Protease assay for halophilic isolates}

The proteolytic activity was assayed using casein as substrate. Casein solution was prepared by dissolving $480 \square \mathrm{l}$ of $1 \%(\mathrm{w} / \mathrm{v})$ casein in $20 \mathrm{mM}$ tris $\mathrm{HCl}$ buffer ( $\mathrm{pH} 8.5), 50 \mathrm{mM} \mathrm{NaCl}$, and $0.5 \mathrm{mM}$ $\mathrm{CaCl}_{2}$. Reaction was carried out by mixing $3 \mathrm{ml}$ of casein solution with $1 \mathrm{ml}$ of crude enzyme and incubated at $55^{\circ} \mathrm{C}$ for $5 \mathrm{~min}$. The reaction was stopped by adding $3 \mathrm{ml}$ of $7.5 \%$ TCA, kept at room temperature for $15 \mathrm{~min}$. and then filtrated using filter paper whatman no. 1 , the absorbance was measured against a blank at $280 \mathrm{~nm}$. One unit of protease activity was defined as the amount of enzyme required to liberate $\square \square \mathrm{mol}$ of tyrosine in 1 min at $60^{\circ} \mathrm{C}$ (Shumi, et al 2004).

\subsection{Effect of growth conditions on protease production}

For maximizing protease production, 3 isolates were selected due to their enzymatic activity. TGY medium was selected as the best medium for protease production.

\subsubsection{Effect of $\mathrm{pH}$ on microbial and protease production}

In order to investigate the influence of $\mathrm{pH}$ on the growth and protease production, $50 \mathrm{ml}$ of TGY medium in $250 \mathrm{ml}$ Erlenmeyer flasks were prepared at different $\mathrm{pH}$ values ranged from 7 to 11 , and inoculated with $1 \mathrm{ml}\left(1.5 \times 10^{8}\right)$ culture. Flasks were incubated at $30^{\circ} \mathrm{C}$ for $48 \mathrm{hrs}$ with shaking at $100 \mathrm{rpm}$. Ten milliliter samples were taken at $2 \mathrm{~h}$ intervals and centrifuged at $15000 \mathrm{rpm}$ for $15 \mathrm{~min}$ at $4^{\circ} \mathrm{C}$ and supernatants were examined for enzyme activity as previously described.

\subsubsection{Effect of temperature on microbial growth and protease production}

To test the effect of temperature on the bacterial growth and alkaline protease production, $50 \mathrm{ml}$ of TGY medium in $250 \mathrm{ml}$ Erlenmeyer flasks were prepared. After inoculation with $1 \mathrm{ml}\left(1.5 \times 10^{8}\right)$ culture, the incubation was carried out at 25, 28, $30,32,34,36$ and $40^{\circ} \mathrm{C}$, using rotary shaker $(100$ $\mathrm{rpm})$ for $24 \mathrm{~h}$. Ten milliliter samples were taken at $2 \mathrm{~h}$ intervals and centrifuged at $15000 \mathrm{rpm}$ for 15 min at $4^{\circ} \mathrm{C}$ and supernatants were examined for enzyme activity as previously described.

\subsubsection{Effect of $\mathrm{NaCl}$ concentrations on bacte- rial growth and protease production}

The effect of salt concentrations on growth and protease production was studied by using TGY medium containing $0-20 \% \mathrm{NaCl}$ concentration at $\mathrm{pH}$ 8. The growth and enzyme activity were quantified during incubation on rotary shaker at $100 \mathrm{rpm}$ at $37^{\circ} \mathrm{C}$ for $72 \mathrm{~h}$.

\subsection{Kinetics of the protease enzyme activity}

\subsubsection{Effect of pH on protease activity}

Effect of $\mathrm{pH}$ on protease activity was studied using $\mathrm{pH}$ levels ranged from $3-12$ in glycine- $\mathrm{HCl}$ buffer ( $\mathrm{pH} 3)$, sodium acetate buffer ( $\mathrm{pH} 4$ and 5), Tris- HCL buffer (from 6 to 9) glycine- $\mathrm{NaOH}$ buffer (11 and 12). Crude enzyme extract and substrate at a ratio of $1: 3$ were mixed in each $\mathrm{pH}$ buffer, and then incubated at $60{ }^{\circ} \mathrm{C}$ for $15 \mathrm{~min}$. then protease activity was measured.

\subsubsection{Effect of Incubation temperature on protease activity}

Crude enzyme extract and substrate with $\mathrm{pH}$ 10 were incubated at different temperatures ranged from 25 to $75^{\circ} \mathrm{C}$ for $15 \mathrm{~min}$, then protease activity was measured at $280 \mathrm{~nm}$ (Shimadzu model UV $160 \mathrm{~A}$ ).

\subsubsection{Effect of Incubation period on protease activity}

$\mathrm{pH} 10$ was the best $\mathrm{pH}$ for protease activity so, crude enzyme extract and casein substrate with $\mathrm{pH}$ 10 were incubated at $60^{\circ} \mathrm{C}$ for different incubation periods ranged from 5 to $95 \mathrm{~min}$, then protease activity was measured at $280 \mathrm{~nm}$ as previously described. 


\subsubsection{Effect of shelf time on protease pro- duction}

The crude protease was incubated at room temperature for 30 days. The percentage of the remaining activity was measured every 10 days. The reaction was stopped in ice-cold water and the remaining activity was measured at $55^{\circ} \mathrm{C}$ in the following buffer systems $0.1 \mathrm{M}$ glycine- $\mathrm{HCl}$ buffer ( $\mathrm{pH} 3), 0.1 \mathrm{M}$ sodium acetate buffer ( $\mathrm{pH} 4$ and 5$)$, $0.1 \mathrm{M}$ Tris HCL buffer (6-9), $0.1 \mathrm{M}$ glycine $-\mathrm{NaOH}$ buffer (11 and 12), respectively, then protease activity was measured at $280 \mathrm{~nm}$. as previously described.

\section{RESULTS AND DISCUSSION}

Ninety five isolates were collected from commercial and laboratory manufactured feseekh products during processing and storage till spoilage occurred and then purified, preserved and tested for their proteolytic ability. The isolates, which showed proteolytic ability in liquid culture media, were finally selected for further studies. Three Bacillus isolates, $11 \mathrm{pb}, 14 \mathrm{pb}$ and $13 \mathrm{pb}$ showed the highest proteolytic activity and were selected for detail studies.

\subsection{Culture conditions affecting protease pro- duction}

\subsubsection{Effect of different media on protease production}

The results in Fig. (1) showed that the enzyme production determined in TGY increased up to 2 fold compared to gelatin medium, casein medium, and $1 \%$ peptone medium. This may be due to the fact that TGY medium contained less easily metabolized able carbohydrates, as reported by Schaffer, 1969, Moon and Paruleker, (1991), Beg et al (2002), also mentioned that the depression of protease synthesis by excess of glucose led to $52 \%$ decline in protease production.

\subsubsection{Effect of using fish by-products on protease production}

Data showed that combined heads and viscera preparations were the best substrate for protease synthesis where the three Bacillus isolates reached the maximum production being $147,136.5$ and $126.3 \mathrm{u} / \mathrm{ml}$ by $11 \mathrm{pb}, 14 \mathrm{pb}$ and $13 \mathrm{pb}$, respectively Fig. (2) compared with artificial media which reached the highest activity using TGY medium to produce $108,79.8,70.6 \mathrm{u} / \mathrm{ml}$ by $11 \mathrm{pb}, 14 \mathrm{pb}$ and
$13 \mathrm{pb}$, after 22, 24, $36 \mathrm{~h}$, respectively. Optimum $\mathrm{pH}, \mathrm{NaCl}$, and temperature of protease production were $8,5 \%$ and $30^{\circ} \mathrm{C}$, respectively. The highest level of protease production was obtained in the presence of head and viscera instead of peptone, (Genckel and Tari, 2006).

Ellouz et al 2001 reported that protease production was significantly low $(108 \mathrm{u} / \mathrm{ml})$, in the presence of meat flour, although this substrate contains more protein than other preparations as shown in Fig. (2), protease synthesis was strongly enhanced when cells were grown on combined heads and viscera powders and there was $100 \%$ increase in the production of protease compared to the original medium. Combined heads and viscera flour contains more lipids and less protein than meat sardinelle, and due to higher bone content, there are minerals. Two hypotheses may be considered to explain the enhancement of protease synthesis when cells were cultivated in the presence of a combined heads and viscera flour. Hypotheses (1), the enzyme might be induced by an excess of salts. This hypotheses seems improbable since the Bacillus subtilis strain produced the same level of protease whether ash, obtained after heating combined heads and viscera at $600{ }^{\circ} \mathrm{C}$ for $24 \mathrm{~h}$, was added to meat fish medium or not. Hypotheses (2), there existed in lipid or protein fractions bioactive molecules that stimulated protease synthesis. In order to study such hypotheses, defatted combined heads and viscera flour was prepared and then tested for protease production. Results presented in Fig. (2), shows that protease activity decreased when lipid content was considerably reduced. A second experiment was realized in order to confirm that combined head and viscera flour contains inducers. Since, lower activity was obtained with meat substrate, culture were conducted in fish media containing both meat fish and combined heads and viscera preparations.

\subsubsection{Effect of temperature, $\mathrm{pH}$ and $\mathrm{NaCl}$ on protease production}

\subsubsection{Effect of temperature on protease production}

Temperature is one of the most important factors affecting enzyme production. The results illustrated in Fig. (3) referred that highest enzyme activity was obtained when Bacillus isolates incubated at $30^{\circ} \mathrm{C}$ for $15 \mathrm{~min}$. to reach 108,108 and 89.28 $\mathrm{u} / \mathrm{ml}$ by $11 \mathrm{pb}, 14 \mathrm{pb}$ and $13 \mathrm{pb}$, respectively. These findings agree with Alsheheri and Mostafa, 2004 where their Bacillus isolate was able to produce maximum production at $30^{\circ} \mathrm{C}$. 


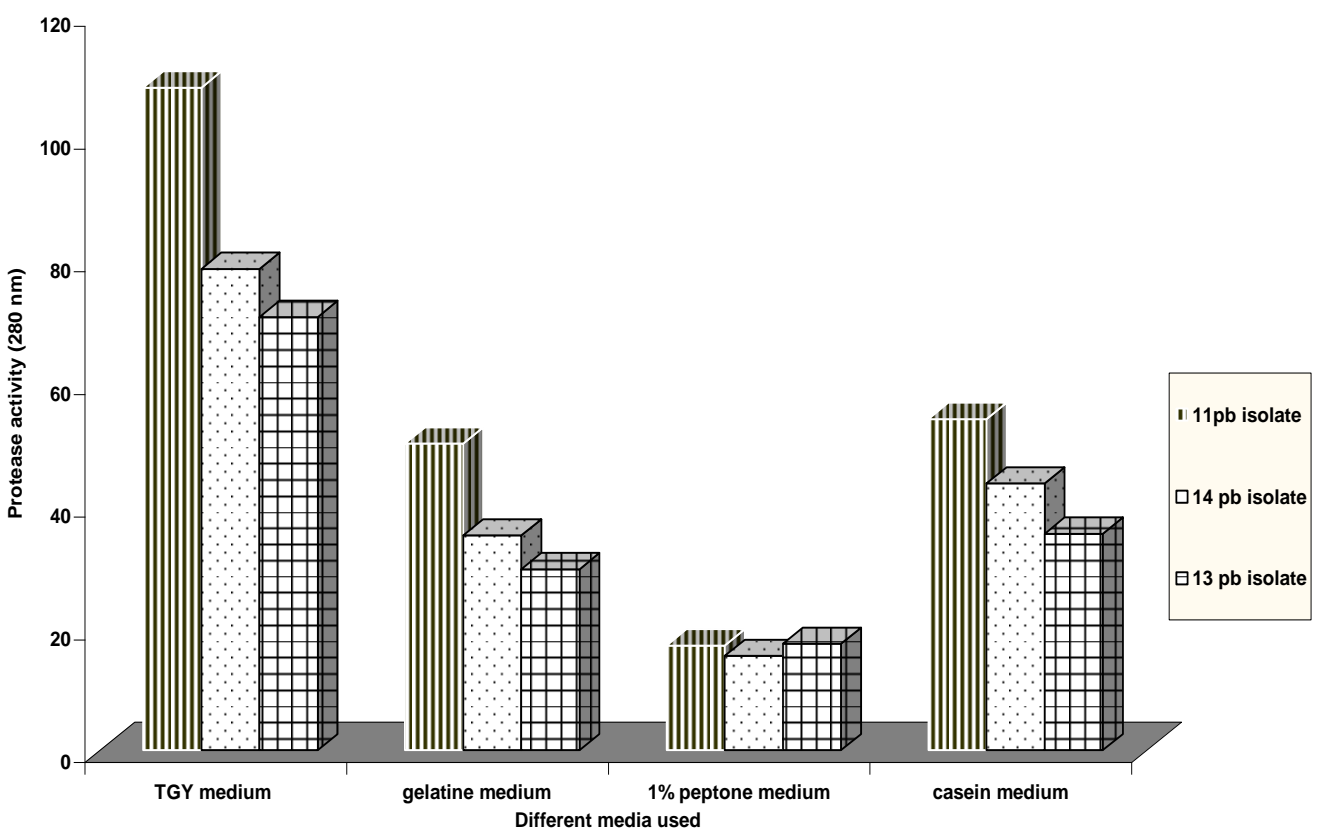

Fig. 1. Effect of different media used for protease production by selected Bacillus spp. Isolates

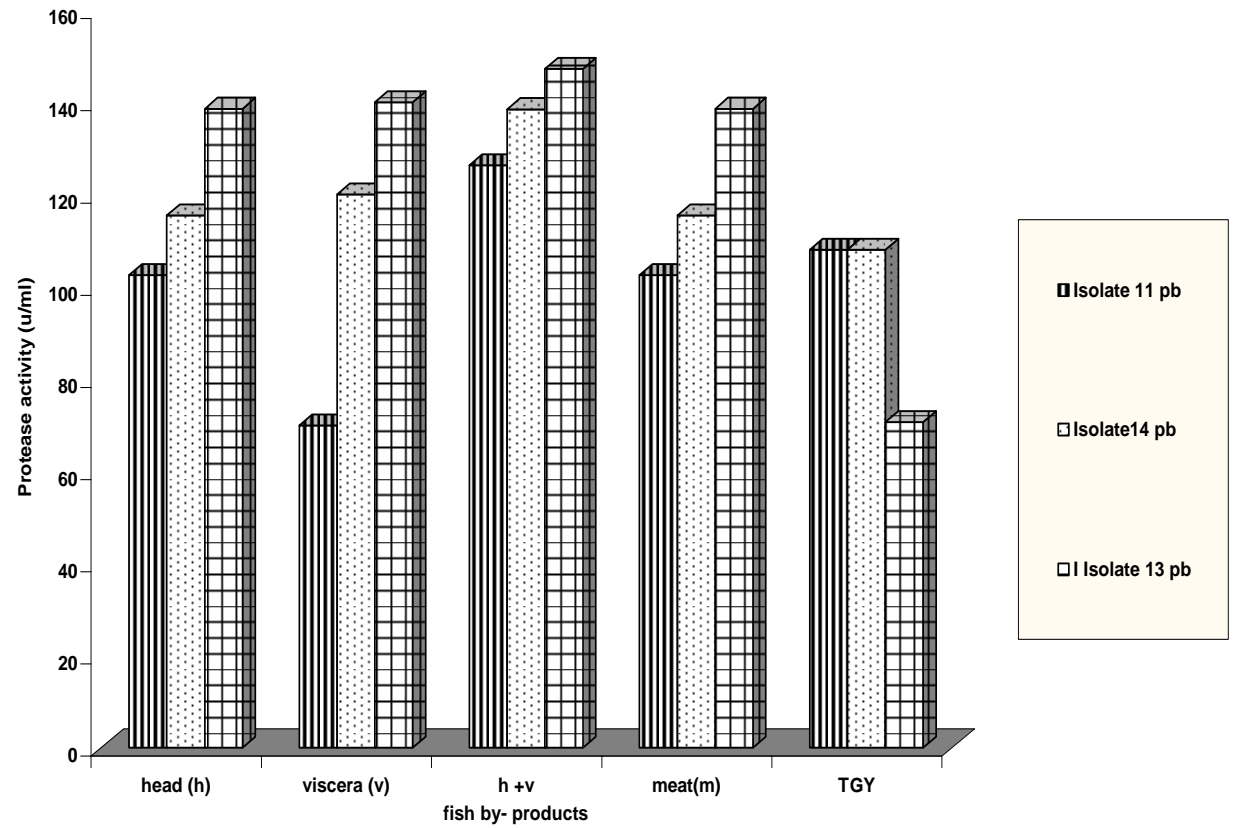

Fig. 2. Effect of fish by-products on protease production by selected Bacillus spp. isolates 


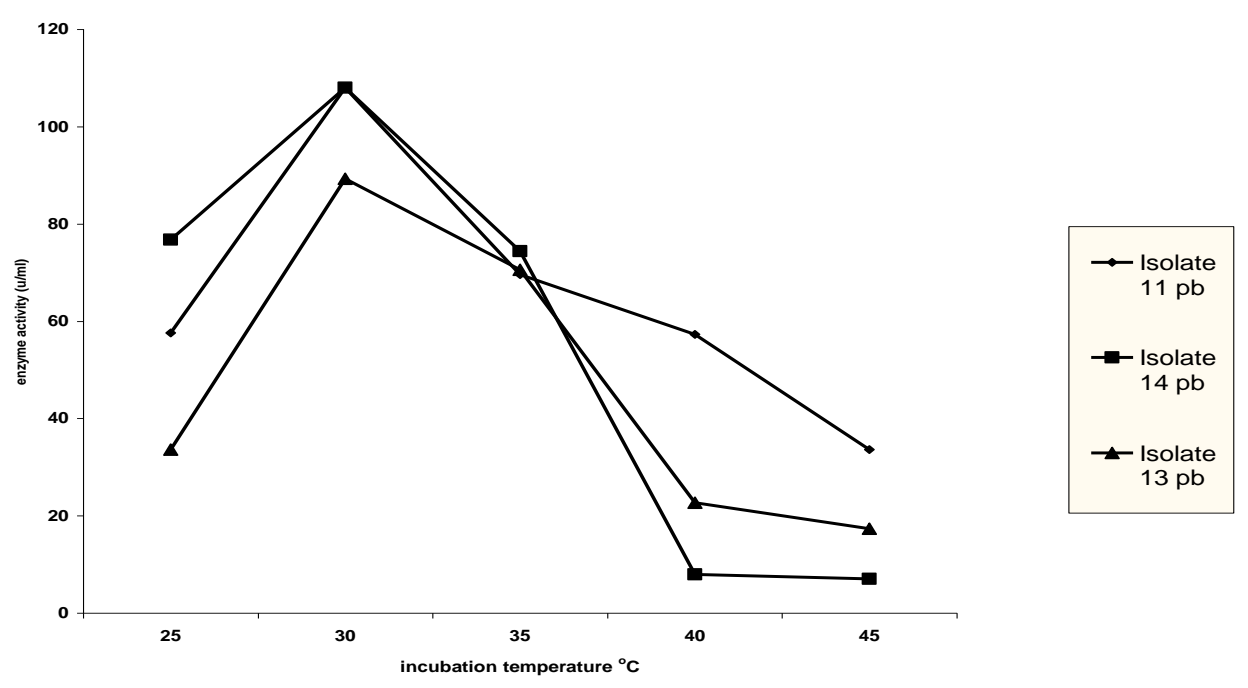

Fig. 3. Effect of temperature on protease production by the selected Bacillus spp. Isolates

\subsubsection{Effect of initial pH on protease production}

Results given in Fig. (4) revealed that the protease production was sensitive to acidic $\mathrm{pH}$. Maximum protease production was obtained at $\mathrm{pH} 8$ and temperature of $30^{\circ} \mathrm{C}$ of reaching $125,112,90$ $\mathrm{u} / \mathrm{ml}$ by $11 \mathrm{pb}, 14 \mathrm{pb}, 13 \mathrm{pb}$, respectively. The enzyme production was gradually decreased by $37.96,44.44$, and $49.14 \%$ for $11 \mathrm{pb}, 14 \mathrm{pb}, 13 \mathrm{pb}$ at $\mathrm{pH} 11$, respectively. These observations were in agreement with the results of Alsheheri, and Mostafa, 2004, \& Joo et al 2002. Their Bacillus isolate was able to produce protease in a broad $\mathrm{pH}$ range from 5.0 to 11.0 and maximum production was observed at $\mathrm{pH} 7.5-9.0$ and temperature of $30^{\circ} \mathrm{C}$.

\subsubsection{Effect of $\mathrm{NaCl}$ on protease production}

The isolate $13 \mathrm{pb}$ grew in the range of $0-20 \%$ (w/v) $\mathrm{NaCl}$, with optimum concentration of $10 \%$ $(\mathrm{w} / \mathrm{v})$. At 0 and $20 \%(\mathrm{w} / \mathrm{v}) \mathrm{NaCl}$, reduction in protease production was observed. The results clearly indicated the halophilic nature of the protease as in Fig. (5). These results are in agreement with Patel, et al (2006), \& Zhang, et al (2007), who indicated that the best concentration of $\mathrm{NaCl}$ for protease production was $5 \%(\mathrm{w} / \mathrm{v})$. The growth of the Bacillus isolate $13 \mathrm{pb}$ was reduced extensively in the absence of salt with no protease production. Similar results have also been reflected by the halo- philic archeon, Natrococcus occultus in which protease secretion was optimum at 1-2 $\mathrm{M} \mathrm{NaCl}$ (\%) (Studdert, et al 1997).

\subsubsection{Time course of protease production using five different media}

Little synthesis of protease was detected during the earlier part of logarithmic growth phase. Protease activity being $88.36 \mathrm{u} / \mathrm{ml}$ at $12 \mathrm{~h}$. A rapid increase in protease production was recorded in the last stage of the logarithmic growth phase. It increased gradually to maximum value of 126.5 , $136.5,147.5 \mathrm{u} / \mathrm{ml}$ by $11 \mathrm{pb}, 14 \mathrm{pb}$ and $13 \mathrm{pb}$ Bacillus sp. isolates, respectively. Thereafter, protease production decreased gradually with cell autolysis. From the profile of protease production and cell growth using TGY medium (Fig. 6). It can be observed that cell growth increases parallel to enzyme production. The present results were supporting the findings of Amozeegar, et al (2007), where they reported that the maximum protease production usually occurs at the late of logarithmic to the beginning of the stationary phase of growth and continued in the stationary phase of the growth. Also, Patel et al 2006 reported that the production thereafter remained nearly static at optimal level along with the stationary phase up to $36 \mathrm{~h}$. Maximum protease production in the basal medium with $10 \%(\mathrm{w} / \mathrm{v}) \mathrm{NaCl}$ was determined in stationary phase (30h), (Karbalaei-Heidari, et al 2007). 


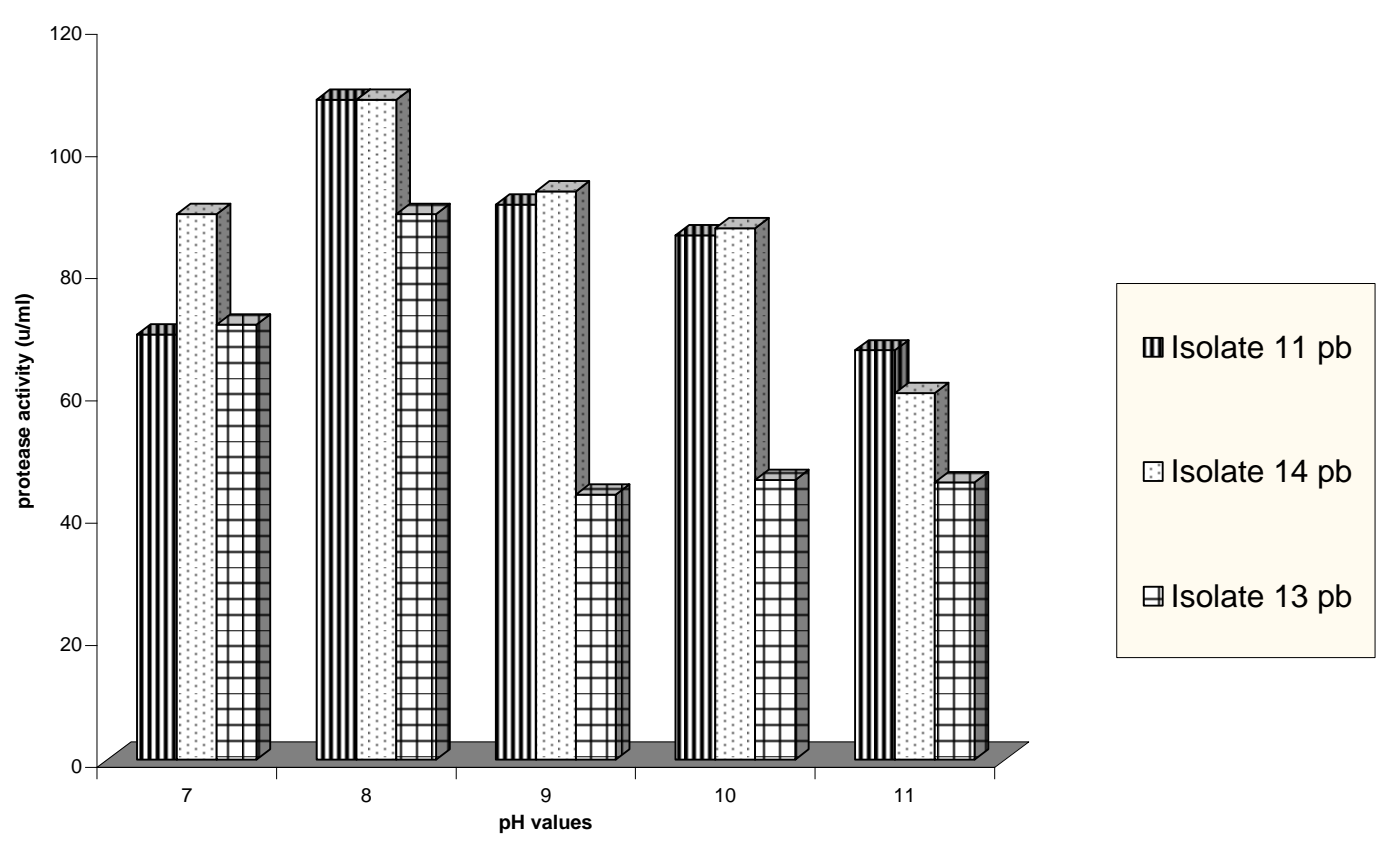

Fig. 4. Effect of pH values on protease production by the selected Bacillus spp. isolates

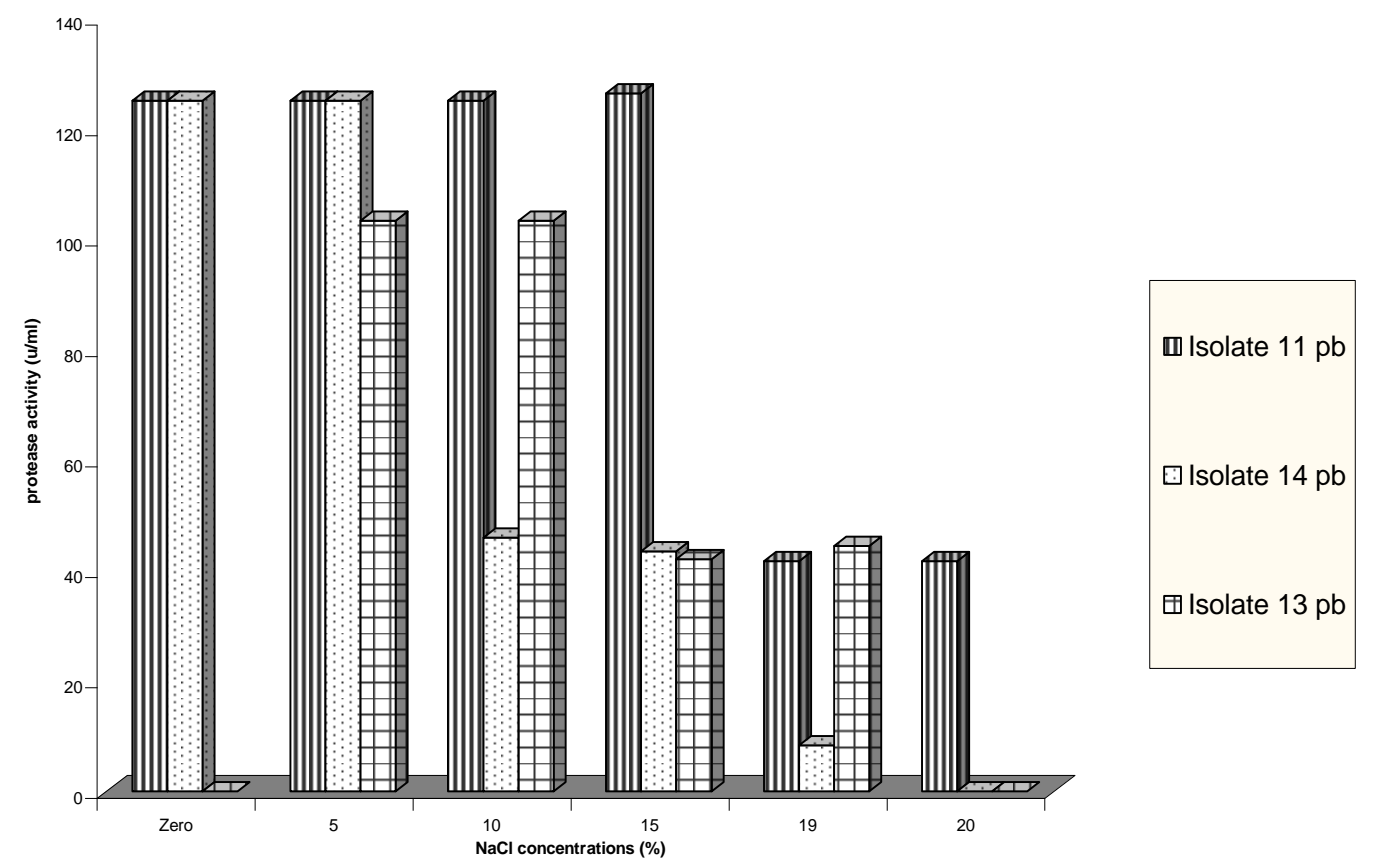

Fig. 5. Effect of $\mathrm{NaCl}$ concentration on protease production by selected Bacillus spp. isolates 

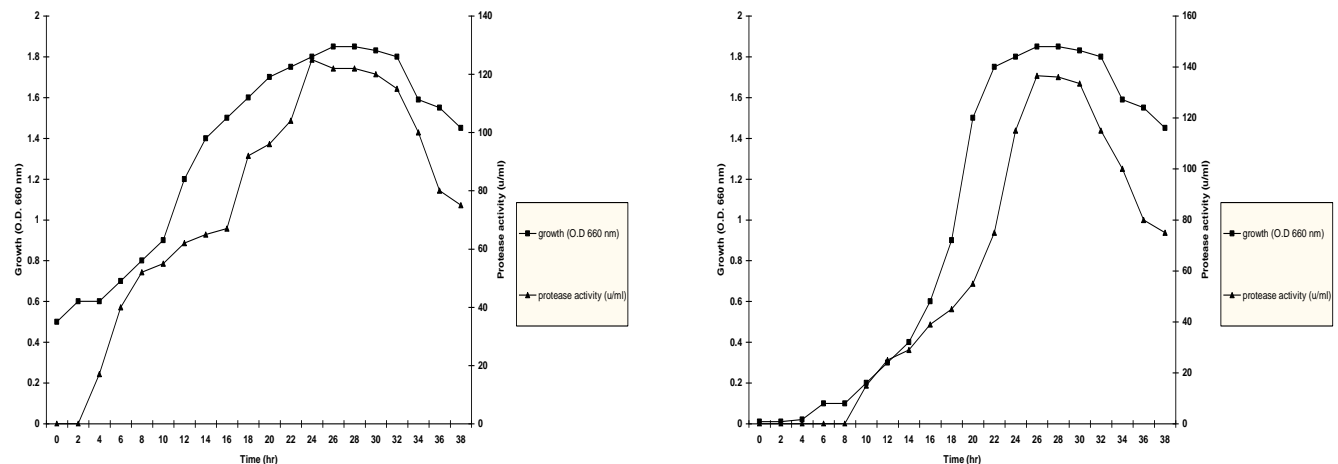

(a)

(b)

(C)

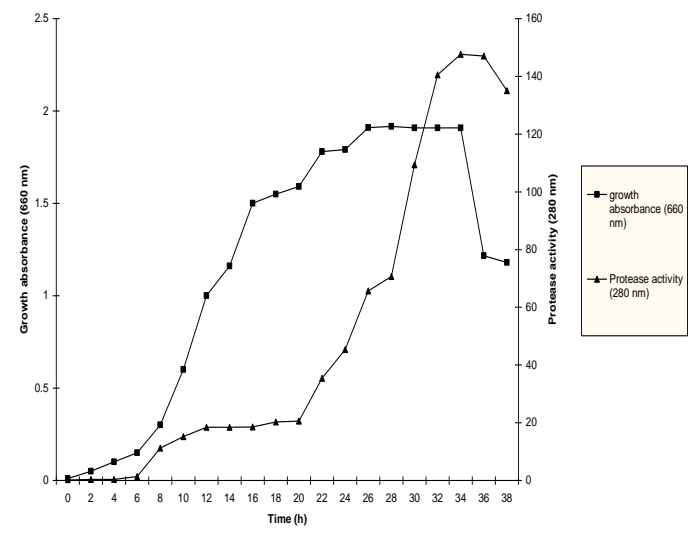

Fig. 6. Kinetics of protease production corresponding to (a) $11 \mathrm{pb}$, (b) $14 \mathrm{pb}$ and (c) $13 \mathrm{pb}$ Bacillus isolates growth rate

3.4. Effect of temperature, $\mathrm{pH}$, incubation time and shelf life on protease activity and stability

\subsubsection{Effect of temperature on protease ac- tivity}

The effect of temperature on the protease activity using casein as substrate was examined at various temperatures for $15 \mathrm{~min}$ at $\mathrm{pH} 10$. As shown in Fig. (7), the maximum enzyme activity was obtained at $65^{\circ} \mathrm{C}$. Then, protease activity decreased. The relative activity at 75 was $46 \%$. The optimum temperature of the crude preparation in the presence of $2 \mathrm{mM}$ of $\mathrm{CaCl}_{2}$ was increased to $70^{\circ} \mathrm{C}$ and the enzyme activity was $10 \%$ obtained without $\mathrm{CaCl}_{2}(65-70 \mathrm{C})$. The thermo activity was increased only at temperature values above $65^{\circ} \mathrm{C}$. A similar result was obtained by (Hadj-Ali, et al 2007), and (Ghorbel, et al 2003).

\subsection{Effect of incubation periods on protease activity}

The effects of incubation periods on the protease activity using casein as substrate were examined at different incubation time in min. at $\mathrm{pH} 10$ and $60^{\circ} \mathrm{C}$. Protease activity was the highest when casein was incubated with the crude enzyme for $15 \mathrm{~min}$ by $11 \mathrm{pb}$ and $13 \mathrm{pb}$ Bacillus isolates while it was required to be incubated for $30 \mathrm{~min}$ to obtain the highest activity by $14 \mathrm{pb}$ Bacillus isolate as illustrated in Fig. (8).

\subsection{Effect of $\mathrm{pH}$ on protease activity}

The $\mathrm{pH}$ profile of the three Bacillus isolates alkaline protease was determined at $60^{\circ} \mathrm{C}$. The enzyme was active in the range of $\mathrm{pH} 8.5$ - 12 with an optimum between $\mathrm{pH} 10$ and 11. There was a sharp decrease in the enzyme activity at $\mathrm{pH}$ lower 


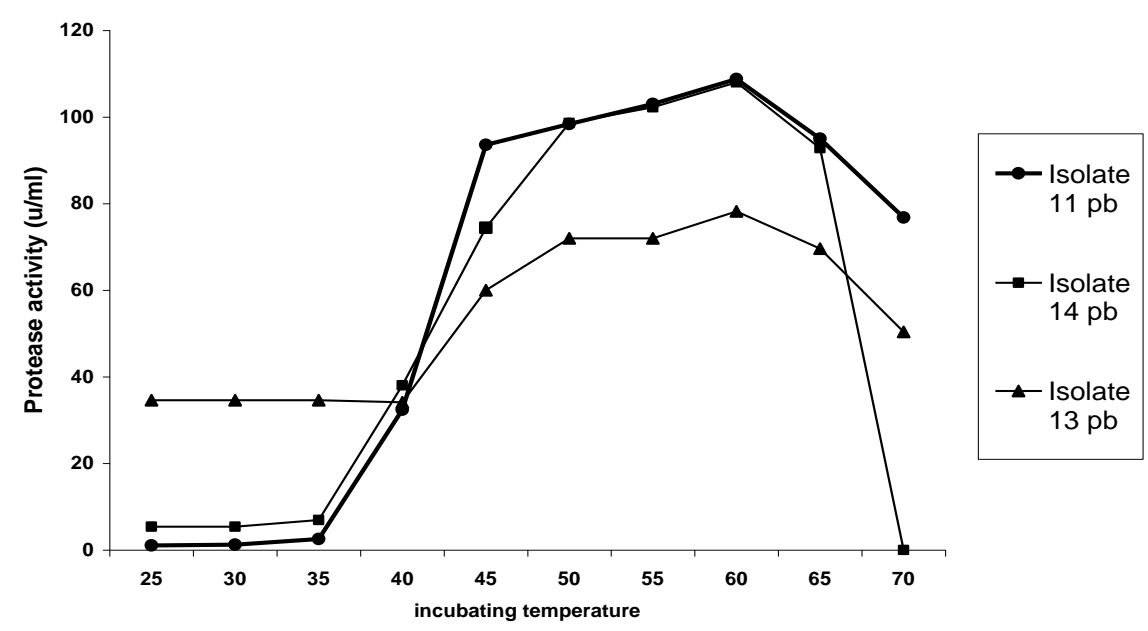

Fig. 7. Effect of incubation temperature on protease activity by selected Bacillus sp. Isolates

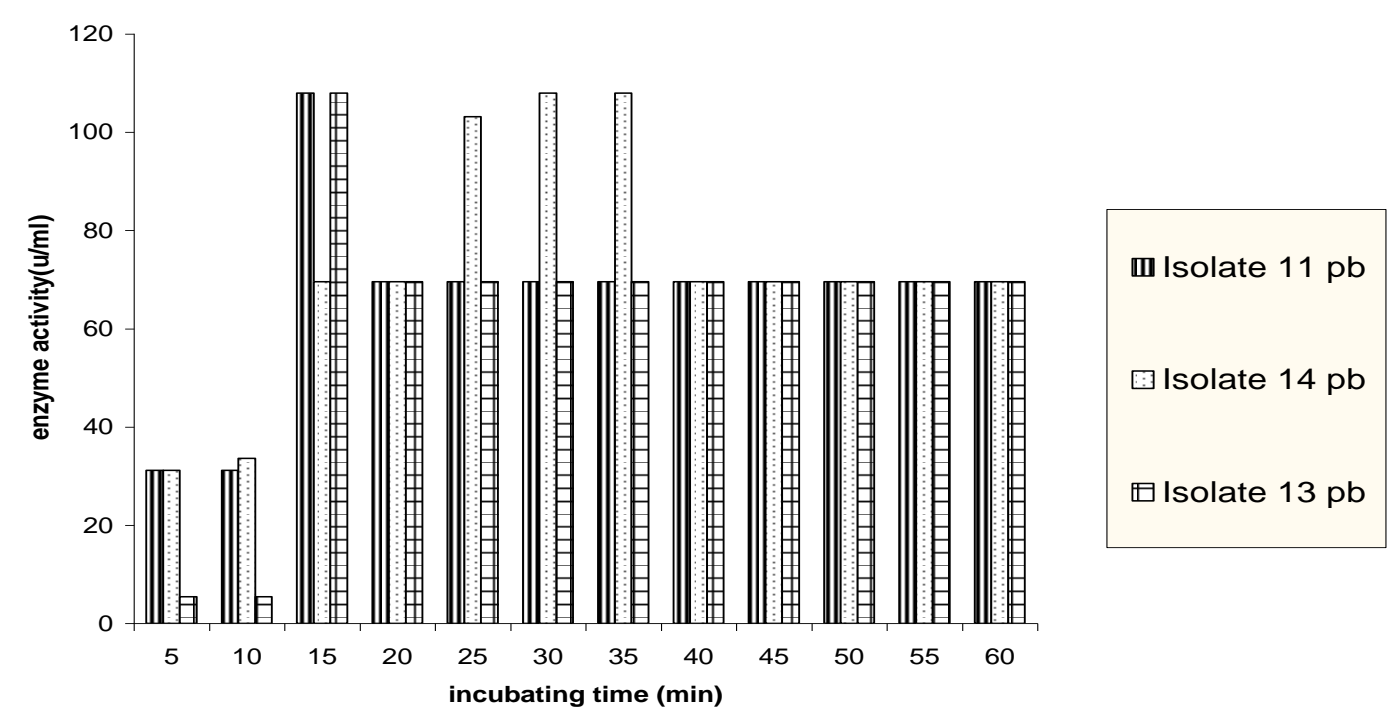

Fig. 8. Effect of incubating period on protease activity and by selected Bacillus sp. isolates

than 9, suggesting the alkaline nature of the enzyme Fig. (9). This range of optimum catalysis is relatively narrow proteases where the optimum catalysis was in the range of $\mathrm{pH}$ 9-12. The protease was optimally active at $\mathrm{pH} 10$ and $60^{\circ} \mathrm{C}$. The enzyme was most active at temperature $60^{\circ} \mathrm{C}$ during the period tested $(1 \mathrm{~h})$. These properties make the enzyme suitable for detergent industry. The effect of $\mathrm{pH}$ on enzyme stability was followed by incubating the enzyme in different buffers 5.0 and 12 for $1 \mathrm{~h}$ at $60^{\circ} \mathrm{C}$, followed by activity estimation at $\mathrm{pH} 10$ and $60^{\circ} \mathrm{C}$. As shown in Fig. (9), the enzyme was stable between $\mathrm{pH} 9$ and 12, and highest stability was observed at $\mathrm{pH} 10$.

\subsection{Effect of storage time on protease activity and stability at room temperature}

Shelf life experiment in Fig. (10) showed that the enzyme retained $95.5 \%$ of its activity for 10 days at room temperature, then lost 10.4, $71.55 \%$ of its activity after 20,30 days, respectively The effect of storage of alkaline protease on its activity was determined as it is an important parameter for commercial utilization of enzyme. These results are on line with Singh et al (1999), who found that the enzyme is $91 \%$ active for 20 days and the activity is reduced to $85 \%$ in 30 days of storage at room temperature suggesting that enzyme may be stored for 20 days at room temperature without much loss in its activity. 


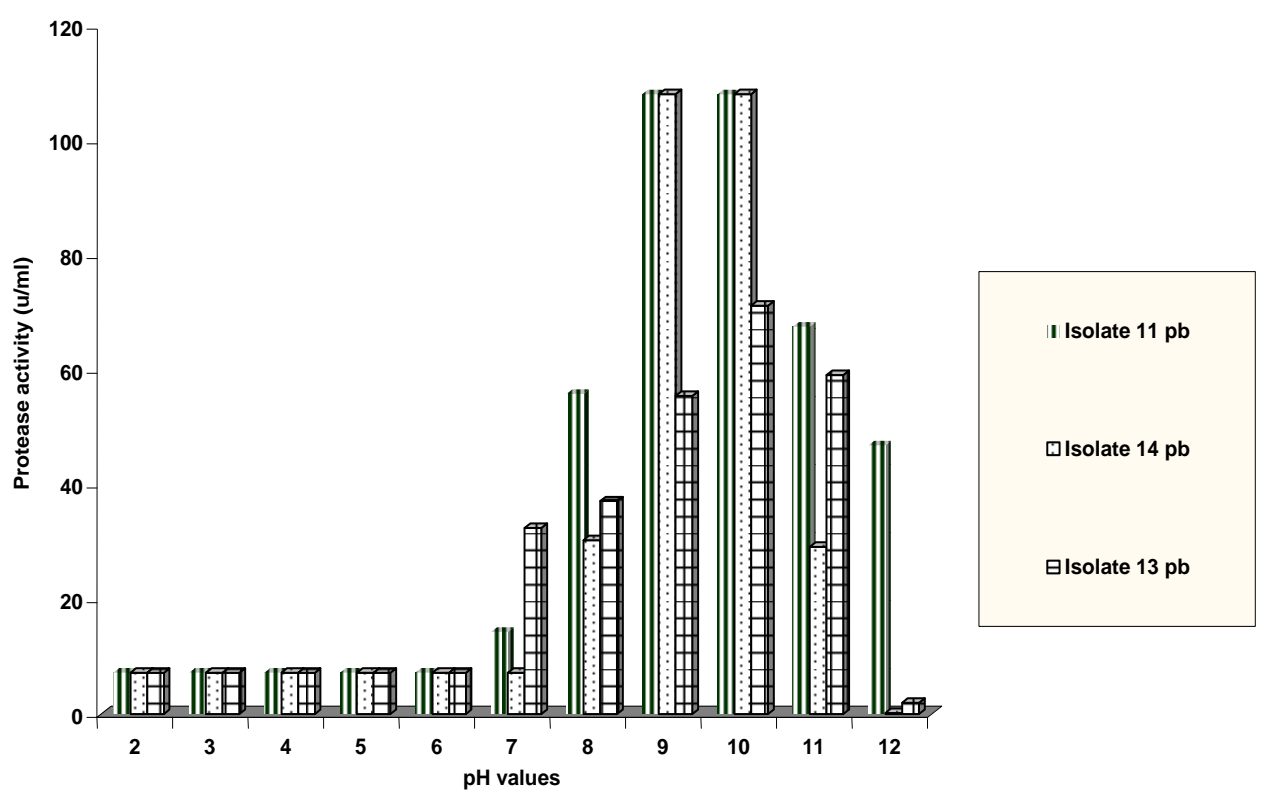

Fig. 9. Effect of pH on protease activity by selected Bacillus sp. Isolates

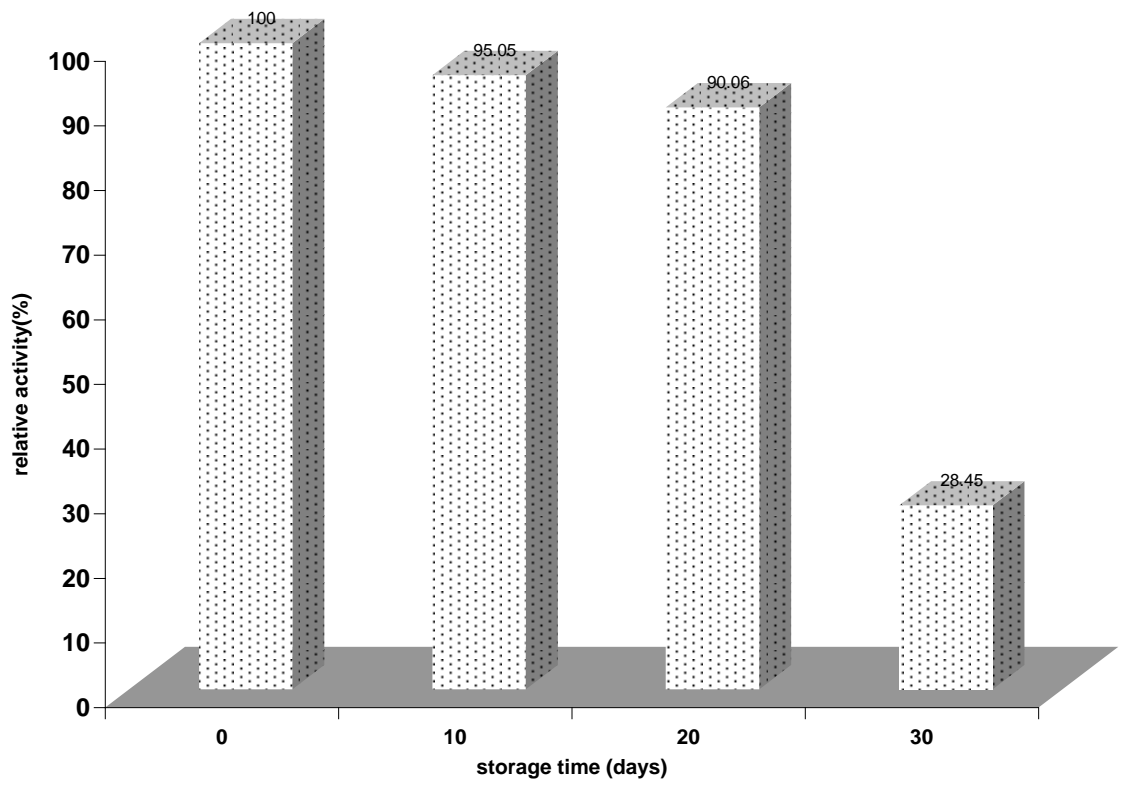

Fig. 10. Effect of storage time on protease stability at $30^{\circ} \mathrm{C}$ for a month by Bacillus sp. isolate $14 \mathrm{pb}$ 


\section{REFERENCES}

Alshehri, M.A. and S.Y. Mostafa (2004). Productin and some properties of protease produced by Bacillus licheniformis isolated from Tihamet Aseer, Saudi Arabia. Pakistan J. Biol. Sci. 7(9): 16311635.

Amozeegar, M.A.; A.Z. Fatemi; H.R. Karbalaeiheidari and M.R. Razavi (2007). Production of an extracellular alkaline mettalo protease from a newly isolated, moderately halophile, Salinivibrio sp. strain AF- 2004. Microbiol. Res. 162(4): 369 377.

An, Y.S.; C.J. Kim and S.Y. Choi (1990). Characteristics of protease from Halobacterium sp. J. Kor. Agric. Chem. Soc. 33: 337-342.

Atalo, K. and B. Gashe (1993). Protease production by thermophilic Bacillus species which degrades various kinds of fibrous proteins. Biotech. Lett., 15: 1151-1156.

Beg, Q.; R. Saxena and R. Gupta (2002). Derepression and subsequent induction of protease synthesis by Bacillus mojavensis under fed- batch operations. Process Biochem. 37: 1103-1109.

Choi, C.; S. Kim; S.I. Im; H.D. Lee; S.H. Lee; J.H. Son; H.J. Choi and Y.H. Kim (1996). Purification and isolation of Bacillus subtilis CCKS-118 protease from traditional soysauce in Korean. Agric. Biotechnol. 39: 460-465.

Choi, H.J. and Y.H. Kim (1997). Purification and isolation of Bacillus subtilis cCKS-118 protease from traditional soysauce in korean. Agric. Biotechnol. 40: 178 - 183.

Ellouz, Y.; A. Bayoudh; S. Kammoun; N. Gharsallah and M. Nasri (2001). Production of protease by Bacillus subtilis grown on sardinelle heads and viscera flour. Bioresource Technol. 80: 4951.

Essuman, K.M. (1992). Fermented fish in Africa, A study on processing, marketing and consumption, FAO Fisheries Technical Paper No.329. 80 pp. FAO. Rome.

FAO, (1992). Food and Agriculture Organization of the United Nations, FAO Fisheries Technical Paper No. 329.

Genckel, H. and C. Tari (2006). Alkaline protease production from alkalopilic Bacillus $\mathrm{sp}$. isolated from natural habitats. Enz. Microbiol. Technol. 39: 703-710.

Ghorbel, B.; A. Sellami-Kamoun and M. Nasri (2003). Stability studies of protease from Bacillus cereus BG1. Enz. Microbiol. Technol. 32: 513518.
Gupta, R.; Q.K. Beg and P. Lorenz (2002). Bacterial alkaline proteases:molecular abroaches and industrial applications. Appl. Microbiol. Biotechnol. 59: $15-32$.

Hadj-Ali, N.E.; R. Agrebi; B. Ghorbel-frivcha; A. Sellami-Kammoun; S. Kanoun and $M$. Nasri (2007). Biochemical and molecular characterization of a detergent stable alkaline serine- protease from a newly isolated Bacillus lichenoformis $\mathrm{NH} 1$. Enz. Microbiol. Technol. 40(4): 515-523.

Joo, H.S; G.C. Kumar; G.C. Park; T.K. Kim; S.R. Paik and C.S. Chang (2003). Oxidant and sds stable alkaline protease from Bacillus clausii I-52: production and some properties. J. Appl. Microbiol. 95: 267-272.

Karabalaei-Heidari, H.R.; A. Ziaee; J. Schaller and M.A. Amoozegar (2007). Purification and characterization of an extracellular haloalkaline protease produced by the moderately halophilic bacterium, Salinivibrio sp. strain AF- 2004. Enz. Microbiol. Technol. 40(2): 266 - 272.

Kembhavi, A.A.; A. Kulharni and A.A. Pant (2007). Salt tolerant and thermostable alkaline protease from Bacillus subtilis NCIM 64. Appl. Biochem. Biotechnol. 38: 38-92.

Kim, W.J. and S.M. Kim (2005). Purification and characteriazation of Bacillus subtilis JM-3 protease from anchovy sauce. J. Food Biochem. 29: 519610.

Ming, C.I.; C. Lee and T. Li (1992). Production and degradation of alkaline protease in batch cultures of Bacillus subtilis ATCC 14416. Enz. Microbiol. Technol. 14-18.

Moon, S. and H. Paruleker (1991). A parametric study of protease production in batch and fed batch cultures of Bacillus firmus. Biotech. Bioeng. 37: 467-483.

Nagao, H. and K.A. To (2000). Purification of collagenase and specificity of its related enzyme from Bacillus subtilis FS-2. Biosci. Biotechnol. Biochem. 64(1): 181-183.

Patel, R.K.; M.S. Dodia; R.H. Joshi and S.P. Singh (2006). Purification and characterization of alkaline protease from a newly isolated halophilic Bacillus sp. Process Biochem. 41: 2002-2009.

Rao, M.B.; A.M. Tanksale; M.S. Ghatge and V.V. Desphande (1998). Molecular and biotechnological aspects of microbial proteases. Microbiol. Mol. Biol. Rev. 62: 597-635.

Rashad, Ferial M. (1986). Bacteriological and Chemical Studies on Salted Mullet Fish 'Feseekh"A traditional fermented fish product in Egypt. pp. 45-46. Ph.D. Thesis, Fac. of Agric, Cairo Univ., Egypt. 
Schaffer, P. (1969). Sporulation and the production of antibiotics, enzymes and exotoxins. Bacteriol. Rev. 33: 48-57.

Shumi, W.; Md. T. Hossain and M.N. Anwar (2004). Proteolytic activity of a bacterial isolate Bacillus fastidiosus den Dooren de jong. J. Biol. Sci. 4(3): 370-374755-761.

Singh, J.; R.M. Vohra and D.K. Sahoo (1999). Alkaline protease from a new alkalophilic isolate of Bacillus sphaericus. Biotechnol. Lett. 21(10): 921 $-924$.

Studdert, C.A.; R.E. Decastro; K.H. Seitz; J. Jorge and J.J. Sanchez (1997). Detection and preliminary characterization of extracellular proteolytic activities of the halophilic archeon Naronococcus occultu. Arch. Microbiol. 168: 532 535.

Su, N.W. and M.H. Lee (2001). Purification and characterization of a novel salt-tolerant protease from Aspergillus sp. FC-10, a soy sauce koji mold. J. Ind. Microbiol. Biotechnol. 26: 253-258.

Watanabe, K. (2003). Fish handling and processing in tropical Africa. In:Proceedings of the FAO Expert Consultation on Fish Technology in Africa, Casablanca, Morocco, 7-11 June 1982. FAO Fish. Rep. Suppl. (268): 1-5.

Yang, J.; I.I. Shih; Y. Tzeng; and S. Wang (2000). Production and purification of protease from Bacillus subtilis that can deproteinize crustacean wastes. Enzyme Microbiol. Technol. 26: 406-413.

Zhang, W.; Y. Xue; Y. Ma.; P. Zhou; A. Ventosa and W.D. Grant (2007). Salinicoccus alkaliphilius sp. nov., a novel alkaliphile and moderate halophile from Baer soda lake in inner Mangolia. Autonomus Region, China. International J. Systematic and Evolutionary Microbiology 52: 789-793. 